\title{
調節可能眼内レンズを挿入した症例の術後早期報告
}

\author{
酒井 幸弘 ${ }^{1)}$ - 宇陀 恵子 ${ }^{1)}$ - 山田 裕子 ${ }^{1)}$ - 内藤 尚久 ${ }^{1)}$ \\ 市川一夫 ${ }^{2)} \cdot$ 小島 隆司 ${ }^{2)} \cdot$ 玉置 明野 ${ }^{2)}$ \\ 1) 中京眼科・ 2) 社会保険中京病院
}

\section{Early result on accommodative IOL implanted eye}

\author{
Yukihiro Sakai ${ }^{1)}$, Keiko Uda ${ }^{1)}$, Yuko Yamada ${ }^{1)}$, Naohisa Naito ${ }^{1)}$ \\ Kazuo Ichikawa $^{2)}$, Takashi Kojima ${ }^{2)}$, Akeno Tamaoki ${ }^{2)}$ \\ 1) Chukyo Eye Clinic, ${ }^{2)}$ Social Insurance Chukyo Hospital
}

\begin{abstract}
要 約
調節が可能といわれている眼内レンズC\&C Vision社CrystaLens AT-45 を挿入する機会を得た。 AT-45 は、支持部への圧力で光学系が前房側に偏位することで調節するとしている。この眼内レン ズを白内障以外に眼疾患を認めず、インフォームドコンセントで同意の得られた 8 例 16 眼（以下 $\mathrm{A}$ 群）に挿入し、術後 3 ケ月までの結果について検討した。コントロールとして、従来型単焦点眼内 レンズCanonstaar社AQ-110NV ${ }^{\circledR}$ 挿入した15例30眼（以下B群）と比較した。

遠見視力は $\mathrm{A}$ 群、 $\mathrm{B}$ 群とも良好であった。片眼および両眼の遠見矯正下近見視力に統計学的な有意 差はないが、加入度数において、有意差を認めた。また、A群の遠見矯正下近見視力は、有意差は ないものの術後 1 ケ月よりも 3 ケ月の方が上がる傾向にあった。コントラスト感度をメニコン社 CAT-2000 で測定した。A 群とB 群に有意差はなく、ほぼ同等の結果となった。A 群とB 群にアン ケートをとった結果、 B 群より A群の方が近くの見え方が良い結果となったが、A群では夜間の見 にくさを訴える症例も多く認められた。RION社 UX-03®でAT-45 の前房側への移動を観察したが、 確認できなかった。多数のAT-45 ${ }^{\circledR}$ 挿入例について報告しているCummingらほど、近見視力に良い 結果は得られなかった。

AT-45 は従来型の単焦点眼内レンズと比較して劣ることはなかったが、調節力に関しては今後さ らに他覚的な検討が必要であると思われた。また、Cummingらは、術後 5 ケ月以上の近方視のトレ ーニングを推奨しており、長期の経過観察が必要と思われる。
\end{abstract}

別冊請求先（テ456-0003）名古屋市熱田区三本松12-23

フォレストインサンショウ 中京眼科

Tel. 052-883-1543 Fax. 052-883-1559

Key words : CrystaLens AT- $45^{\oplus}$, Distance-corrected near acuity, accommodatoin, intra ocular lens CrystaLens AT-45 、遠見矯正下近見視力、調節、眼内レンズ 


\begin{abstract}
We have experienced implantation of CrystaLens AT- $45^{\circledR}$ (C\&C Vision), which is said to have accommodative effect on the implanted eye. The optics of the AT- $45^{\oplus}$ moves forward by the mechanical force of the ciliary muscle to the haptics. Sixteen eyes of 8 patients, hereinafter A group, were used under informed consent and 3 months follow up were made to check the accommodative effect. Thirty eyes of 15 patients of conventional silicone IOL AQ-110NV ${ }^{\oplus}$ (CANONSTAAR), hereinafter B group, were used as a control group. Both A and B groups obtained good distance vision. Although there was no statistical difference in distance-corrected near acuity between both groups, the additional power of A group was statistically lower than that of B group. The distancecorrected near acuity of group A in 3 months after the surgery tend to become better than that in 1 month after, but statistically no difference. The contrast sensitivity of the both groups was found to be almost the same using CAT- $2000^{\circ}$, Menicon. From a questionnaire, group A had better subjective near vision than group B. 25\% of the group A complained of poor night vision. The movement of AT- $45^{\oplus}$ was not observed by UX- $03^{\oplus}$, RION. The near vision in our study was not good as those reported by Cumming et al. It was shown that AT- $45^{\oplus}$ had no disadvantage against conventional monofocal IOLs; however, no significant advantage was found in our early result. As Cumming et al. has suggested that near vision training over 5 months after surgery is preferable to obtain good accommodation, further investigation on the accommodation of long term follow up using objective test is needed.
\end{abstract}

\section{I．緒言}

現在、白内障手術はほぼ完成の域に達したと 言っても過言ではないと思われる ${ }^{1)}$ が、その中 でさらなるQuality of lifeを求め、老視治療の要 求は高まってきている213!。我々は、調節が可 能といわれている眼内レンズ C\&C Vision社 CrystaLens AT- $45^{\oplus}$ (図 1 ) を挿入する機会を 得たので、術後早期の結果について報告する。

この眼内レンズは光学径が $4.5 \mathrm{~mm}$ 、全径が $11.5 \mathrm{~mm}$ で、シリコーン製のmodified plate haptics、polyimide製のループで構成されてい る。支持部への圧力で、光学系が前房側に偏位 することで調節するとしている。ただし、水晶 体囊内に眼内レンズが固定され、囊収縮により 眼内レンズが囊と接触することが条件となる ${ }^{3)}$ 。 今回は、CrystaLens AT-45 尚挿入した症例の 術後 3 ケ月までの近方視の評価について検討し た。
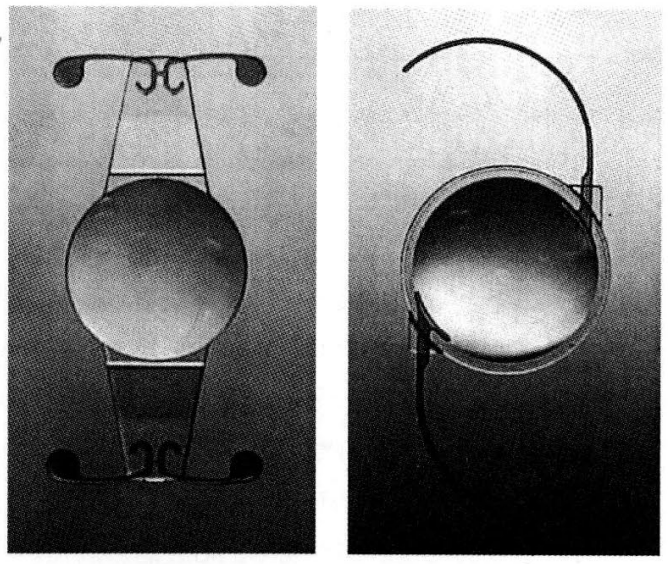

図 1. C\&C Vision社CrystaLens AT-45® (左写真) とCanonstaar 社 $\mathrm{AQ}-110 \mathrm{NV}{ }^{\circledR}$ (右写真)

\section{II . 症例および方法}

症例は白内障以外に眼疾患を認めず、インフ オームドコンセントでAT-45 を挿入することに 同意の得られた 8 例 16 眼 (以下 $\mathrm{A}$ 群) を対象と した。術前平均等価球面度数は- $0.05 \pm 1.22 \mathrm{D}$ で、 
術後 3 ヶ月の平均等価球面度数 $-0.29 \pm 0.44 \mathrm{D}$ 、 平均裸眼視力 $1.04(0.3 \sim 1.5)$ 、平均矯正視力 1.42 （1.2〜 1.5)、平均年齢は66.3 \pm 9.0 歳だった。

方法は、眼軸長の測定を水浸式超音波 $\mathrm{A}$ モー ド (ジャパンフォーカス社AXIS II $\left.{ }^{\circledR}\right)$ 、角膜曲率 半径はOphthalmometer (Inami社) にて測定し た。水浸式超音波 A モードとOphthalmometer での測定は、AT- $45^{\oplus}$ 発注の際、この検査機器 によるデータでの注文が義務づけられていたた め使用したが、測定に関しては通常使用してい

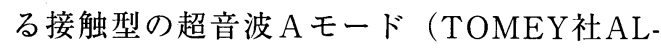
$\left.2000^{\varpi}\right) 、 Z e i s s$ 社IOLMaster ${ }^{\mathrm{TM}}$ 、オートケラトメ ー夕（NIDEK社ARK-700A ${ }^{\circledast}$ ) で確認している。 いずれの症例も術後は正視を目標とし、SRK-T 式にて眼内レンズ度数を計算した。使用した眼 内レンズの度数は、+21.5 +24.5Dであった。

手術は同一術者が、点眼麻酔下にて角膜耳側 切開によるPEA + IOLを施行し、眼内レンズは AT- $45^{\oplus}$ を囊内に挿入した。全例、術中合併症は 起こらなかった。調節麻痺をさせた状態で、水 晶体囊に眼内レンズを固定させるために、手術 の終了直後と翌日の診察終了後に $1 \%$ 硫酸アト ロピンを点眼した。

$\mathrm{A}$ 群のコントロールとして、白内障以外に眼 疾患を認めず、従来型単焦点眼内レンズ Canonstaar社AQ-110NV ${ }^{\circledR}$ (図 1) を抻入した症 例 15 例 30 眼（以下 B 群）と比較した。AQ$110 \mathrm{NV}^{\circledast}$ の眼内レンズは、光学系が $5.5 \mathrm{~mm}$ 、全径 は12.5mm、Opticsはシリコーンで、ループは polyimideで構成されている。B群の術後の平均 等価球面度数は $-0.29 \pm 0.61 \mathrm{D}$ 、平均裸眼視力は、 $0.90(0.3 \sim 1.5)$ 、平均矯正視力は $1.40(1.2 \sim 1.5)$ 、 平均年齢は $69.5 \pm 6.6$ 歳だった。 A 群と B 群の二 群間はいずれにおいても有意差はなかった。

今回の検討項目として、術後 3 ケ月での近見 視力、コントラスト感度、アンケート結果を $\mathrm{B}$ 群と比較した。

近見は、片眼及び両眼の遠見矯正下近見視力、 矯正視力、加入度数を測定した。近見視力測定 は検者を 2 名に固定し、検查距離が約 $33 \mathrm{~cm} 、$ 室 内の照度が約500luxの条件で行った。コントラ スト感度は、メニコン社CAT-2000にて、昼間 時（視標輝度 + 背景輝度 $: 100 \mathrm{~cd} / \mathrm{m} 2$ ) と薄暮時
（視標輝度 +背景輝度： $5 \mathrm{~cd} / \mathrm{m} 2 ）$ の条件で測定 した。

A 群に対して超音波画像診断装置RION社UX$03^{\circledast}$ を用い、毛様体及びAT- $45^{\circledast}$ の移動を観察し た。測定は、仰臥位にて主に耳側から毛様体筋 と眼内レンズが観察されるよう眼球にプローブ を当て、他眼にて $2 \mathrm{~m}$ の遠見視標を見た時と、 眼前 $30 \mathrm{~cm}$ 付近を固視した時をそれぞれ測定し た。

また、近見視力について多数のAT- $45^{\oplus}$ 挿入例 について報告しているCummingら ${ }^{4)}$ の結果と A 群の術後 1 ケ月と 3 ケ月を比較した。

\section{III. 結 果}

片眼の遠見矯正下近見視力は $\mathrm{A}$ 群で $0.31 、 \mathrm{~B}$ 群では 0.21 、両眼の遠見矯正下近見視力は $\mathrm{A}$ 群 で0.49、B群では0.36で、両群ともA 群の方がよ い結果になったが、統計学的な有意差は認めら れなかった $(\mathrm{t}$ 検定 : 片眼 $\mathrm{p}=0.12$ 、両眼 $\mathrm{p}=0.074)$ (表 1 )。近見矯正視力は両群ともに 1 眼のみ 0.9 だった以外は全て1.0だった。加入度数は A群で $+2.30 \pm 0.57 \mathrm{D} 、 \mathrm{~B}$ 群で+2.72 $00.28 \mathrm{D}$ でA群にお いて加入度数がより少ない結果になり、有意差 が認められた（ $\mathrm{t}$ 検定： $\mathrm{p}=0.0016 ） 。$

$\mathrm{A}$ 群の術後の経過（図 2) において、統計学 的に有意差はないが、片眼の遠見矯正下近見視

表 1. 近見視力の結果

\begin{tabular}{|c|c|c|}
\hline & A群 & $\mathrm{B}$ 群 \\
\hline 片眼遠見矮正下 & $0.31(0.1 \sim 0.8)$ & $0.21(0.1 \sim 0.6)$ \\
\hline 両眼遠見矯正下 & $0.49(0.3 \sim 0.9)$ & $0.36(0.3 \sim 0.7)$ \\
\hline 堭正梘力 & 1 眼のみ 0.9 、他は 1.0 & I眼の久 0.9 、他忙 1.0 \\
\hline 加人度数 * & $\begin{array}{c}+2.30 \pm 0.57 \mathrm{D} \\
(+1.00 \mathrm{D} \sim+3.00 \mathrm{D})\end{array}$ & $\begin{array}{c}+2.72 \pm 0.28 \mathrm{D} \\
(+2.25 \sim+3.00 \mathrm{D})\end{array}$ \\
\hline
\end{tabular}

(*t敛定 : $\mathrm{p}=0.0016)$

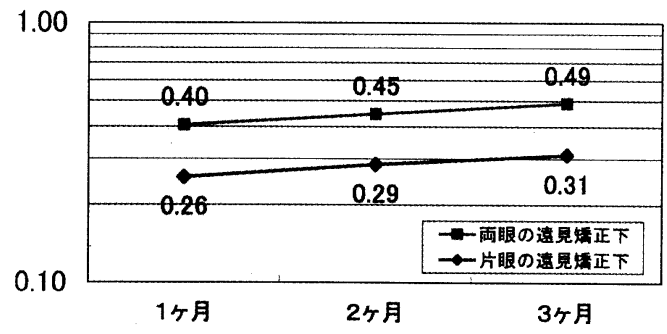

図 2.AT-45®の遠見矯正下近見視力の術後の経過 
力は術後 1 ヶ月で $0.26 、 2$ ヶ月で $0.29 、 3$ ヶ月で 0.31 、両眼の遠見矯正下近見視力は術後 1 ケ月 で0.40、2 2 月で $0.45 、 3$ ケ月で 0.49 と徐々に上 がる傾向にあった。

CAT-2000でのコントラスト感度測定（図 3， 4) は、昼間時でA群がややよく、薄暮時では 両群に差がない結果となった。両群間には、い ずれにおいても統計学的な有意な差は認められ なかった。

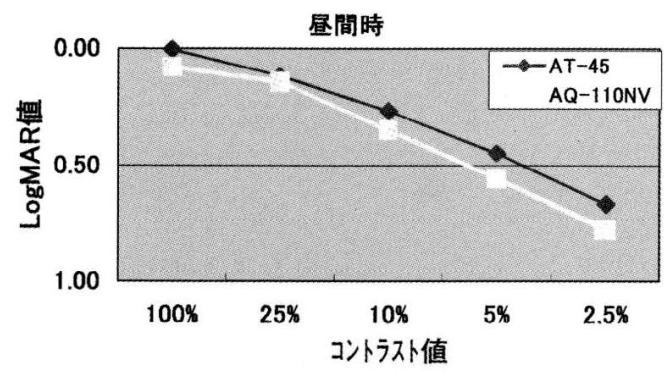

図 3. 昼間時 (視標輝度 + 背景輝度 : $100 \mathrm{~cd} / \mathrm{m} 2$ ) の コントラスト感度

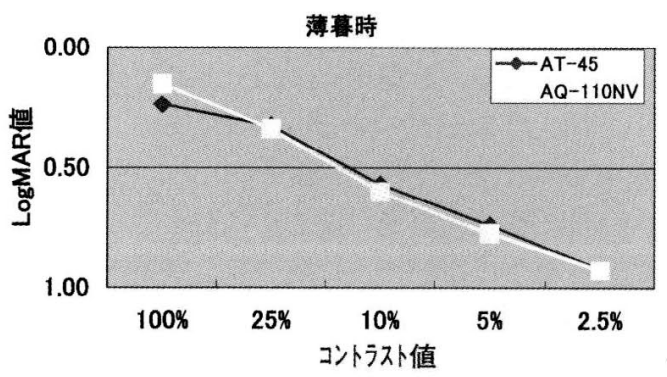

図 4. 薄暮時 (視標輝度+背景輝度 : $5 \mathrm{~cd} / \mathrm{m}^{2}$ ) のコ ントラスト感度

A群と B 群にアンケートをとった結果を表 2 に示す。1 3 は近くの見え方についての質問 である。1〜3のうち、「新聞の記事は読めま すか」という質問に対し、A群は「読める」と の回答の割合が50\%と B 群より高く、「老眼鏡が ないと不自由ですか」という質問では、A群の 症例で老眼鏡が必要な方の割合は $38 \%$ B B 群よ り低かった。4つ目の「手術前と比べて夜間に 見にくいことがありますか」という質問に対し、 A 群で、「見にくい」と答える症例が $25 \%$ とや や多い結果になった。
表 2. アンケート内容と結果
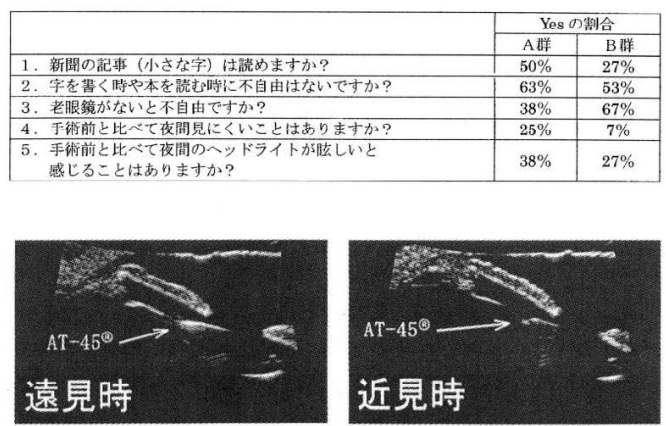

図 5.RION社UX-03 の超音波画像の所見

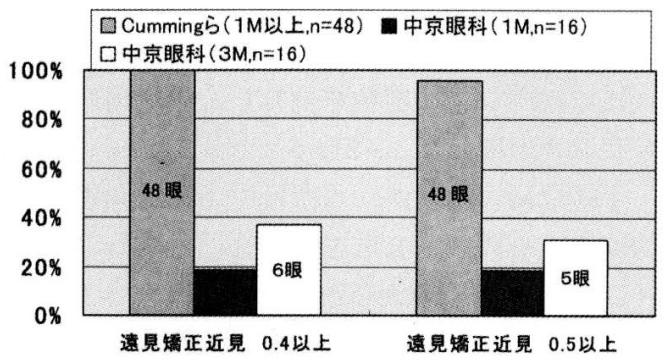

図 6. Cummingらとの遠見矯正下近見視力の比較

UX-03 での測定結果（図 5 ）は、近見反応と しての瞳孔運動は認められるも、眼内レンズの 前房側への偏位は観察できなかった。

Cummingらとの近見視力の比較（図 6 ）は、 片眼の遠見矯正下近見視力 0.4 以上がCumming らの症例で、48眼100\%に対して、A群では、術 後 3 ヶ月で 6 眼 $37.5 \%$ 、0.5以上が、Cumming ら の症例 46 眼 $96 \%$ に対して、A群では、術後 3 ケ 月で 5 眼 $31.25 \%$ と低い割合となり、Cumming らの症例ほど良い結果は得られなかった。

\section{IV. 考 察}

調節可能眼内レンズはmultifocal IOLとは異 なり、レンズの光学部は通常の眼内レンズと同 様の単焦点であり、支持部の構造上の特徵によ って調節を行っているとされている。AT- $45^{\circledR}$ の 素材は現在広く用いられているシリコーンで、 小切開で挿入可能であるため、従来型のレンズ と比べ光学部径が小さい事以外、機能的に不利 な点はないと考えられる。今回の遠見視力、コ 
ントラスト感度の結果において、AT-45®は従来 型の単焦点眼内レンズと比較して劣ることはな かった。しかし、アンケート結果で夜間の見え 方が手術前より悪くなる症例を認めた。これは 有効光学径が $4.5 \mathrm{~mm}$ と小さいため、暗所におい て収差が大きくなることが考えられる。アンケ 一ト時にA群で夜間見にくいと訴えた症例は、 術後経過するにつれて徐々に改善傾向にあると 言っているため、今後は他覚的な検討も含めて 経過観察が必要であると考えられる。

遠見矯正下近見視力では、Cummingらほど良 い結果は得られなかったが、B群と比較し、加 入度数において有意差が認められた。近見視力 は術後 1 ヶ月から 3 ヶ月にかけて上昇傾向にあ りアンケート結果からも自覚的にはA群の方が 近くの見え方がよいのではないかと感じられた。 UX-0 $0{ }^{\oplus}$ での超音波の画像からはAT- $45^{\circledR}$ の前房 側への移動は確認できず、調節力に関しては今
後さらに他覚的な検討が必要であると考えられ る。また、Cummingらは、 5 ケ月上の近方視 のトレーニングを推奨しており、長期の経過観 察が必要と思われる。

\section{参考文献}

1 ）綾木雅彦，他：白内障手術と眼内レンズの最 新トピックス。あたらしい眼科19：271-272, 2002

2 ）木下 茂，他：老視への対処法.あたらしい 眼科 $1819 ： 1231,2001$

3 ）木下 茂，他：屈折矯正手術 Q \& A．あたら しい眼科18 臨増：237-239, 2001

4) J. Stuart Cumming : Clinical Evaluation of the Model AT-45 Silicone Accomodating Intraocular Lens. 2005-2010,Ophthalmology Vol.108 No.11 Nov.2001 